\title{
Effects of Antioxidants on Oxidant-induced Sister Chromatid Exchange Formation
}

\author{
Alan B. Weitberg, Sigmund A. Weitzman, Edward P. Clark, and Thomas P. Stossel \\ Hematology-Oncology Unit, Departments of Medicine and Radiation Medicine, Massachusetts General Hospital Cancer Center, \\ Harvard Medical School, Boston, Massachusetts 02114
}

\begin{abstract}
Stimulated human phagocytes produce sister chromatid exchanges in cultured mammalian cells by a mechanism involving oxygen metabolites. Experiments were designed to determine whether antioxidants inhibit this process.

Superoxide dismutase, catalase, and hydroxyl radical scavengers (benzoate, mannitol) protected target Chinese hamster ovary cells from phagocyte-induced sister chromatid exchanges, implicating the involvement of hydroxyl radicals in this chromosomal damage. $N$-acetylcysteine and $\beta$-carotene were also protective.

$\alpha$-Tocopherol ( $>5 \mu \mathrm{M})$ protected target cells exposed to phagocytes but not to enzymatically generated oxidants when the vitamin was added just before the source of oxygen radicals, suggesting, as reported by others, that the principal action of tocopherol in this setting was to inhibit the release of oxidants from phagocytes. On the other hand, cultivation of target cells with supplemental tocopherol protected them from the toxic effects of the enzymatic oxidant-producing system, indicating a role for membrane-associated free radicals in the mechanism of sister chromatid exchange induction.

Low concentrations of sodium selenite (0.1-1.0 $\mu \mathrm{M})$ protected the target cells. However, higher concentrations (10 $\mu M)$ of selenite had no effect on oxidant-induced sister chromatid exchange formation, and $0.1 \mathrm{mM}$ selenite increased the number of exchanges. Sodium selenite concentrations of 0.1 $\mathrm{mM}$ also decreased the intracellular glutathione concentration of target cells during an oxidant stress, and reducing target cell glutathione concentrations with buthionine sulfoximine increased their sensitivity to oxygen-related chromosomal damage. Therefore, the potentiation of oxygen radical-induced chromosomal damage observed with high concentrations of selenite may result from a decrease in the thiol antioxidant defense systems within the cell.

The findings suggest that $(a)$ the hydroxyl radical has an important role in the production of phagocyte-induced cytogenetic injury, (b) membrane-derived intermediates may be involved, (c) depletion of intracellular glutathione renders cells more susceptible to this injury, and $(d)$ supplementation of target cells with antioxidants can protect them from oxygen radical-generated chromosomal injury.
\end{abstract}

Dr. Weitberg is the recipient of The American Cancer Society Junior Faculty Fellowship. Address reprint requests to Dr. Weitberg, Cox Building, Massachusetts General Hospital.

Received for publication 17 August 1984 and in revised form 28 December 1984

J. Clin. Invest.

(c) The American Society for Clinical Investigation, Inc.

0021-9738/85/06/1835/07 $\$ 1.00$

Volume 75 , June 1985, 1835-1841

\section{Introduction}

Phagocytic leukocytes synthesize toxic oxygen metabolites that are important for the killing of microorganisms $(1,2)$. These oxygen-derived products also can kill host cells (3). We have shown that normal human phagocytes stimulated to produce toxic oxygen metabolites cause mutations in bacteria and sister chromatid exchanges (SCEs) ${ }^{1}$ in cultured mammalian cells (4, $5)$. On the other hand, phagocytes from patients with chronic granulomatous disease (CGD) do not have these effects. In that CGD phagocytes are unable to elaborate oxygen metabolites $(6,7)$, it can be inferred that these metabolites play a primary role in the generation of phagocyte-mediated genetic damage. In addition, an enzymatic, cell-free system for elaborating toxic oxygen products can produce SCEs (5). Such sublethal effects of oxidants could be involved in the carcinogenesis associated with certain inflammatory conditions. In support of this idea, phagocyte- and enzyme-generated oxidants transform mammalian cells in vitro $(8,9)$.

A variety of biologic and chemical reagents influence the production and disposition of toxic oxygen compounds. It is interesting to examine the effects of such agents on oxygenmediated toxicity, because the results of such study can help elucidate the mechanism of damage. Furthermore, the ability of certain of these substances to minimize genetic effects may have potential for designing strategies to reduce the carcinogenic influence of inflammation. To investigate further the role of phagocyte-generated oxygen metabolites in the genesis of SCEs, we examined the effects of enzymes and chemicals affecting toxic oxygen metabolites and cellular defenses against these compounds on the production of oxidant-induced SCEs in cultured mammalian cells.

\section{Methods}

Tissue culture cells. Chinese hamster ovary (CHO) cells were maintained in modified Ham's F10 medium (Gibco Laboratories, Grand Island, NY) and $1 \%$ penicillin/streptomycin (Gibco Laboratories) in a humidified incubator at $37^{\circ} \mathrm{C}$. Culture flasks $\left(25 \mathrm{~cm}^{2}\right)$ were seeded with 2 $\times 10^{5}$ to $3 \times 10^{5} \mathrm{CHO}$ cells from a single exponentially growing culture with a doubling time of $12-14 \mathrm{~h}$. In some experiments, $\mathrm{CHO}$ cells were preincubated with an antioxidant, which was present continuously for $72 \mathrm{~h}$ before seeding the flasks.

Isolation of human phagocytes. Leukocytes were isolated from anticoagulated human blood by dextran sedimentation under sterile conditions (10), suspended in Hanks' balanced salt solution (Gibco Laboratories) and used within $30 \mathrm{~min}$ of preparation (11). Cytochrome $c$ reduction by human phagocytes was assayed by the method of Babior et al. (12).

1. Abbreviations used in this paper: BSO, DL-buthionine-SR-sulfoximine; CHO, Chinese hamster ovary; PMA, 12-O-tetradecanoylphorbol-13acetate; $\mathrm{SCE}(\mathrm{s})$, sister chromatid exchange. 
SCE assay. $24 \mathrm{~h}$ after the $\mathrm{CHO}$ cell experimental culture flasks were plated, the medium was removed and one of the following reagents was added: superoxide dismutase, catalase, benzoate, $N$-acetylcysteine, sodium selenite, D-L- $\alpha$-tocopherol acid succinate (vitamin E), $\beta$-carotene (all from Sigma Chemical Co., St. Louis, MO) and mannitol (Mallinckrodt Chemical Works, St. Louis, MO) followed by $10^{7}$ leukocytes. Some flasks were also treated with $12-O$-tetradecanoylphorbol-13-acetate (PMA) (Lot 29, Consolidated Midland, Brewster, NY) to activate the oxidative metabolism of the phagocytes (13). Controls consisted of $\mathrm{CHO}$ cells alone as well as $\mathrm{CHO}$ cells plus PMA, CHO cells plus $10^{7}$ unstimulated leukocytes, or $\mathrm{CHO}$ cells plus each of the antioxidants added individually. In some experiments, an enzymatic superoxide-generating system was used in place of activated phagocytes. This system consisted of hypoxanthine $(7 \mu \mathrm{g} / \mathrm{ml})$ and xanthine oxidase $(15 \mu \mathrm{g} / \mathrm{ml})$ (Sigma Chemical Co.) added in the presence and absence of an antioxidant. Cytochrome $c$ reduction by hypoxanthine/xanthine oxidase was assayed by the method of McCord and Fridovich (14).

The flasks were incubated for $30 \mathrm{~min}$ at $37^{\circ} \mathrm{C}(8 \mathrm{~min}$ for hypoxanthine/xanthine oxidase), the supernatant was washed out and replaced with $10 \mathrm{ml}$ of a medium enriched with $2.5 \times 10^{-5} \mathrm{M}$ 5-bromo-2'deoxyuridine (Sigma Chemical Co.) and incubated for $30 \mathrm{~h}$ as described by Latt (15). $3 \mathrm{~h}$ before harvesting, $0.2 \mathrm{ml}$ of colcemide (Sigma Chemical Co. $)(22.5 \mu \mathrm{g} / \mathrm{ml})$ was added to each flask.

After harvesting, the cells were hypotonically swollen with 0.075 $M$ potassium chloride for $12-13 \mathrm{~min}$ and subsequently washed three times with absolute methanol/glacial acetic acid (3:1). Of this suspension, $0.2 \mathrm{ml}$ was dropped from a distance of $8-15 \mathrm{~cm}$ onto glass slides held at an angle to rupture the cells. Chromosomes were stained with the fluorescence plus Giemsa method (16), and SCEs were counted by scoring at points of discontinuity in staining and reported as the mean number of exchanges per metaphase after at least 30 metaphases per data point were counted. Metaphases were counted in a coded fashion without the scorer knowing the nature of the experimental incubation.

Total glutathione measurement. Total glutathione (GSH + GSSG) was determined by the GSSG reductase-5,5'-dithio-bis2-nitrobenoic acid recirculating assay using a modification $(17,18)$ of the Tietze method (19).

Glutathione depletion. In some experiments we wished to study the effects of depletion of the intracellular antioxidant, glutathione. For this purpose, $\mathrm{CHO}$ cells were routinely cultured in a $250-\mathrm{ml}$ spinner flask (Bellco Glass, Vineland, NJ) containing McCoy's 5A medium plus $10 \%$ fetal calf serum and the antibiotics $(100 \mu \mathrm{g} / \mathrm{ml})$ penicillin and streptomycin as previously described (18). The cells were maintained in exponential growth by appropriate dilution of the spinner flask three times a week; the cell population doubling time was approximately $14 \mathrm{~h}$ under these conditions. Cells were placed in $25-\mathrm{cm}^{2}$ flasks $24 \mathrm{~h}$ before the experiment to yield $10^{6}$ cells per flask on the day of the experiment. All flasks were initiated from the spinner cultures. The cells were incubated for $24 \mathrm{~h}$ in the presence of $0.1 \mathrm{mM}$ DL-buthionineSR-sulfoximine (BSO) (Chemalog, South Plainfield, NJ), which resulted in total glutathione levels of $<10 \%$ of control at the end of the $24-h$ incubation.

\section{Results}

Fig. 1 shows the effect of the enzymes superoxide dismutase and catalase on the number of SCEs produced in CHO cells by phorbol ester-stimulated human phagocytes. Superoxide dismutase and catalase significantly $(P<0.0005)$ reduced the number of phagocyte-induced SCEs, whereas the heat-inactivated enzymes had no effect.

The results observed with the hydroxyl radical scavenger mannitol, are illustrated in Fig. 2. A dose-dependent decrease

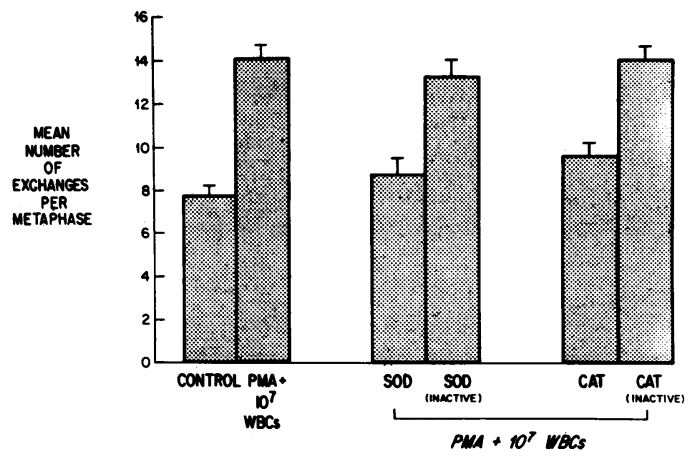

Figure 1. The effect of superoxide dismutase (SOD), catalase (CAT), and heat-inactivated superoxide dismutase and catalase on phagocytegenerated SCEs. Enzymes were heat-inactivated by autoclaving for 30 $\min$ at $132^{\circ} \mathrm{C}$. The concentration of superoxide dismutase was 100 $\mu \mathrm{l} / \mathrm{ml}$ and catalase was $220 \mu \mathrm{l} / \mathrm{ml}$. PMA was used in a concentration of $100 \mathrm{ng} / \mathrm{ml}$. The bars indicate mean \pm SD of 30 determinations.

in SCEs is demonstrated, with near-complete inhibition observed at mannitol concentrations of $10 \mathrm{mM}$ or greater.

The effects of benzoate, another hydroxyl radical scavenger, and $N$-acetylcysteine, a sulfhydryl compound are shown in Fig. 3. Benzoate and $N$-acetylcysteine effectively lowered the number of phagocyte-generated SCEs.

The effect of vitamin E on phagocyte-induced SCEs is shown in Table I. There was a significant reduction in exchanges when vitamin $\mathrm{E}$ was added concomitantly to the incubations. To determine whether this protective effect was due to the interaction between vitamin $E$ and oxidants alone, these experiments were repeated using hypoxanthine and xanthine oxidase in place of phagocytes. As shown in Table I, vitamin $\mathrm{E}$ had no protective effect when oxidants were generated by a cell-free system. The rates of superoxide formation by the enzyme system and the PMA-stimulated leukocytes under the conditions employed were comparable (104 and $175 \mathrm{nmol} /$ incubation, respectively). The results from using $\beta$-carotene in similar experiments are shown in Table II. In contrast to the

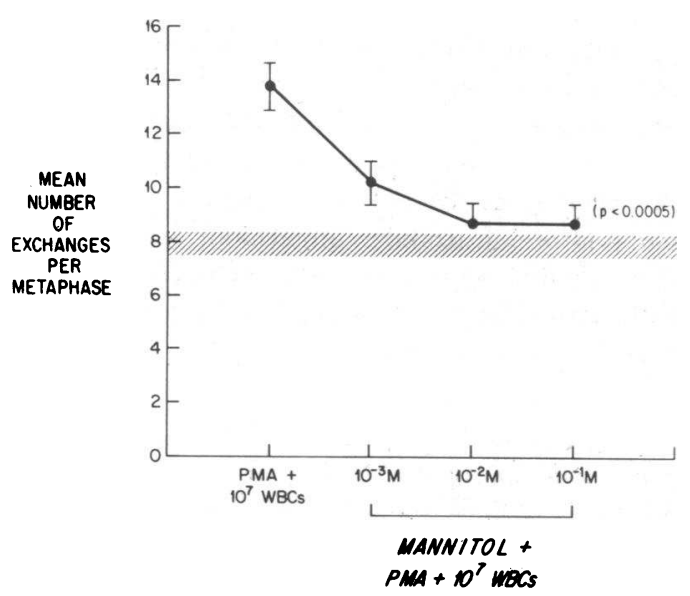

Figure 2. The effect of mannitol on phagocyte-induced SCEs. PMA was used in a concentration of $100 \mathrm{ng} / \mathrm{ml}$. Each point indicates the mean \pm SD of 30 determinations. Shaded area, control range. 


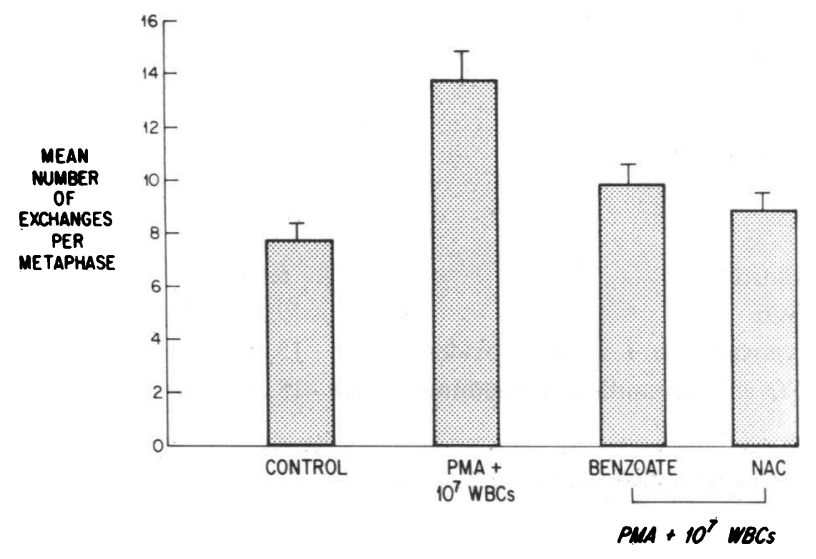

Figure 3. The effect of benzoate and $N$-acetylcysteine (NAC) on phagocyte-generated SCEs. Benzoate was used in a concentration of $25 \mathrm{mM}, N$-acetylcysteine in a concentration of $10 \mathrm{mM}$, and PMA in a concentration of $100 \mathrm{ng} / \mathrm{ml}$. The bars indicate mean $\pm S D$ of 30 determinations.

findings with vitamin $E$, the presence of $\beta$-carotene in the incubations effectively protected against the generation of SCEs by both phagocytic and enzymatically generated oxygen metabolites.

When $\mathrm{CHO}$ cells pretreated with vitamin $\mathrm{E}, \beta$-carotene or both were exposed to hypoxanthine plus xanthine oxidase, there was a highly significant reduction in exchanges compared to controls (Table III). Thus, vitamin $\mathrm{E}$ was able to protect

Table I. Effect of Vitamin E on Phagocyte-induced and Enzymatically Generated SCEs

\begin{tabular}{|c|c|}
\hline Additions to cell cultures & SCEs \pm SEM $\ddagger$ \\
\hline 1 Control & $7.89 \pm 0.93$ \\
\hline 2 PMA $+10^{7} \mathrm{WBCs}^{*}$ & $12.58 \pm 0.42 \S$ \\
\hline $3 \mathrm{PMA}+10^{7} \mathrm{WBCs}+$ vitamin E $\left(5 \times 10^{-6} \mathrm{M}\right)$ & $8.60 \pm 0.27^{\prime \prime}$ \\
\hline \multirow[t]{2}{*}{$4 \mathrm{PMA}+10^{7} \mathrm{WBCs}+$ vitamin $\mathrm{E}\left(10^{-5} \mathrm{M}\right)$} & $8.30 \pm 0.48 \pi$ \\
\hline & SCEs \pm SEMł‡ \\
\hline 1 Control** $^{* *}$ & $7.82 \pm 0.23$ \\
\hline $\begin{array}{l}2 \text { Hypoxanthine + xanthine oxidase } \\
\text { Hypoxanthine + xanthine oxidase }\end{array}$ & $10.95 \pm 0.28 \S \S$ \\
\hline $3+$ vitamin $\mathrm{E}\left(10^{-6} \mathrm{M}\right)$ & $10.60 \pm 0.24 \S \S$ \\
\hline+ vitamin $\mathrm{E}\left(10^{-5} \mathrm{M}\right)$ & $10.00 \pm 0.25 \S \S$ \\
\hline
\end{tabular}

* The concentration of PMA used was $100 \mathrm{ng} / \mathrm{ml}$. WBCs, leukocytes. $\ddagger$ Pooled data from three experimental preparations; 90 metaphases counted per data point.

$\S P<0.0005$ vs. 1 .

" $P<0.0025$ vs. 2.

I $P<0.0005$ vs. 2 .

** Controls consisted of $\mathrm{CHO}$ cells alone as well as $\mathrm{CHO}$ cells plus hypoxanthine and $\mathrm{CHO}$ cells plus xanthine oxidase.

$\ddagger \ddagger$ Pooled data from two experiments; 60 metaphases counted per data point.

$\S P<0.0005$ vs. 1 .
Table II. Effect of $\beta$-Carotene on Phagocyte-induced and Enzymatically Generated SCES

\begin{tabular}{|c|c|}
\hline Additions to cell cultures & SCES \pm SEM \\
\hline 1 Control & $7.34 \pm 0.39$ \\
\hline 2 PMA $+10^{7}$ WBCs $^{*}$ & $12.00 \pm 0.75 \ddagger$ \\
\hline \multicolumn{2}{|l|}{ PMA + $10^{7}$ WBCs } \\
\hline $3+\beta$-carotene $\left(5 \times 10^{-6} \mathrm{M}\right)$ & $9.70 \pm 0.86 \S$ \\
\hline \multirow[t]{2}{*}{$+\beta$-carotene $\left(10^{-5} \mathrm{M}\right)$} & $8.80 \pm 0.44^{\prime \prime}$ \\
\hline & SCES \pm SEM** \\
\hline \multirow{3}{*}{\multicolumn{2}{|c|}{$\begin{array}{l}1 \text { Controlf } \\
2 \text { Hypoxanthine + xanthine oxidase } \\
3 \text { Hypoxanthine + xanthine oxidase }\end{array}$}} \\
\hline & \\
\hline & \\
\hline$+\beta$-carotene $\left(10^{-5} \mathrm{M}\right)$ & $14.90 \pm 1.30 \$ \S$ \\
\hline
\end{tabular}

* The concentration of PMA used was $100 \mathrm{ng} / \mathrm{ml}$. WBCs, leukocytes. $\ddagger P<0.01$ vs. 1 .

$\S P<0.0025$ vs. 2 .

" $P<0.0005$ vs. 2 .

7 Controls consisted of $\mathrm{CHO}$ cells alone as well as $\mathrm{CHO}$ cells plus hypoxanthine and $\mathrm{CHO}$ cells plus xanthine oxidase.

** Pooled data from two experimental preparations; 60 metaphases counted per data point.

$\ddagger P<0.0005$ vs. 1 .

$\$ P<0.0005$ vs. 2 .

the target $\mathrm{CHO}$ cells if they were grown in it for $72 \mathrm{~h}$, but it was not protective when added acutely during the test incubations.

The effect of sodium selenite had variable effects on the number of SCEs generated depending on the concentration added, as shown in Table IV. The high concentrations of sodium selenite caused an augmentation in the number of SCEs, whereas at lower concentrations, a protective effect was observed.

To try to determine why high concentrations of sodium selenite cause an augmentation in the amount of oxygen radical-induced genetic damage, we examined the effect of

Table III. Effect of Preincubation with Vitamin E and $\beta$-Carotene on Enzymatically Generated SCEs

\begin{tabular}{lr}
\hline Additions to cell cultures & \multicolumn{1}{c}{ SCES \pm SEM } \\
\hline 1 Control & $8.43 \pm 0.59$ \\
2 Hypoxanthine + xanthine oxidase & $22.57 \pm 1.79^{*}$ \\
$\quad$ Hypoxanthine + xanthine oxidase & \\
$3 \quad+$ preincubation with vitamin $\mathrm{E}\left(10^{-5} \mathrm{M}\right)$ & $11.30 \pm 0.73 \ddagger$ \\
$4 \quad+$ preincubation with $\beta$-carotene $\left(10^{-5} \mathrm{M}\right)$ & $10.70 \pm 0.97 \ddagger$ \\
$5 \quad+$ preincubation with vitamin $\mathrm{E}\left(10^{-5} \mathrm{M}\right)$ and \\
$\quad \beta$-carotene $\left(10^{-5} \mathrm{M}\right)$ & $9.93 \pm 0.70 \ddagger$
\end{tabular}

$* P<0.0005$ vs. 1 .

$\ddagger P<0.0005$ vs. 2 . 
Table IV. Effect of Sodium Selenite on Enzymatically Generated SCES

\begin{tabular}{|c|c|c|}
\hline \multicolumn{2}{|c|}{ Additions to cell cultures } & \multirow{2}{*}{$\begin{array}{l}\text { SCEs } \pm \text { SEM } \\
9.53 \pm 0.56 \ddagger\end{array}$} \\
\hline & & \\
\hline & $\begin{array}{l}+ \text { xanthine oxidase } \\
+ \text { xanthine oxidase }\end{array}$ & $20.24 \pm 1.18 \ddagger \S$ \\
\hline 3 & + sodium selenite $\left(10^{-4} \mathrm{M}\right)$ & $26.04 \pm 1.40 \ddagger^{\prime \prime}$ \\
\hline 4 & + sodium selenite $\left(10^{-5} \mathrm{M}\right)$ & $20.20 \pm 1.13$ \\
\hline 5 & + sodium selẹnite $\left(10^{-6} \mathrm{M}\right)$ & $14.71 \pm 1.28^{\prime \prime}$ \\
\hline 6 & + sodium selenite $\left(10^{-7} \mathrm{M}\right)$ & $10.16 \pm 0.52^{\prime \prime}$ \\
\hline
\end{tabular}

* Controls consisted of $\mathrm{CHO}$ cells alone as well as $\mathrm{CHO}$ cells plus hypoxanthine, $\mathrm{CHO}$ cells plus xanthine oxidase and $\mathrm{CHO}$ cells plus sodium selenite at each concentration listed above.

$\ddagger$ Pooled data from two experimental preparations; 60 metaphases counted per data point.

$\S P<0.0005$ vs. 1 .

" $P<0.0005$ vs. 2 .

selenite on cellular glutathione levels. As shown in Table $\mathrm{V}$, CHO cells were able to maintain glutathione levels despite exposure to hypoxanthine and xanthine oxidase. However, in the presence of $0.1 \mathrm{mM}$ selenite and an oxidant stress, glutathione levels fall to $\sim 75-80 \%$ of controls and there was a corresponding increase in genetic toxicity. Sodium selenite alone (in the absence of an oxidant stress), at $10^{-4} \mathrm{M}$ and $10^{-5}$ $\mathbf{M}$ caused slight increases in glutathione levels, whereas at $10^{-3}$ $M$, the glutathione level fell to $84 \%$ of control. Sodium selenite, by itself, in concentrations of $10^{-3}$ and $10^{-5} \mathrm{M}$ did not affect SCE rates.

To assess the effect of glutathione depletion on the susceptibility of the target cell to oxidant-induced damage, $\mathrm{CHO}$ cells were incubated with BSO for $24 \mathrm{~h}$ before exposure to an oxidant stress. BSO is a potent inhibitor of the enzyme $\gamma$-glutamylcysteine synthetase which catalyzes the initial step in glutathione synthesis. Total glutathione levels at the end of this incubation are $<10 \%$ of controls. As shown in Table VI, there was a slight, but significant increase in sister chromatid exchanges in cells incubated with BSO alone and this effect was magnified in cells treated with BSO and exposed to an oxidant stress. Furthermore, this combined treatment produced additional obvious effects on DNA replication as well: the proportion of cells that had gone through one, instead of two,
Table VI. SCEs in BSO-treated Cells Exposed to Hypoxanthine and Xanthine Oxidase

\begin{tabular}{lcc}
\hline Additions to cell cultures & SCEs \pm SEM & $\begin{array}{c}\text { Delayed } \\
\text { metaphases }\end{array}$ \\
& & $\%$ \\
& & $\%$ \\
1 Control* & $6.64 \pm 0.38$ & 0 \\
2 BSO $¥$ & $9.16 \pm 0.50 \S$ & 0 \\
3 Hypoxanthine + xanthine oxidase & $13.40 \pm 0.85$ & $<10$ \\
4 BSO + hypoxanthine + xanthine oxidase & $18.20 \pm 1.42^{11}$ & 75
\end{tabular}

* Control consisted of $\mathrm{CHO}$ cells alone.

¥ BSO concentration was $0.1 \mathrm{mM}$.

$\S P<0.0005$ vs. 1 .

II $P<0.0005$ vs. 2 .

rounds of DNA replications was also determined as described by Tice et al. (20). First-division cells contain chromosomes with both sister chromatids uniformly dark as opposed to second-division cells in which chromosomes have one chromatid darkly stained and its sister lightly stained. $75 \%$ of the cells incubated with BSO and exposed to hypoxanthine and xanthine oxidase were delayed in first metaphase, whereas the effect on DNA replication was minimal in the other experimental groups.

\section{Discussion}

Among other toxic oxygen-derived metabolites, activated neutrophils produce hydroxyl radicals by a mechanism believed to involve a metal-catalyzed Haber-Weiss reaction. This reaction requires the participation of both superoxide anions and hydrogen peroxide (21). Because superoxide dismutase or catalase alone each had inhibitory effects on SCE production, the hydroxyl radical is indirectly implicated as an important oxygen metabolite leading to SCE formation, although this data is indirect. The fact that the hydroxyl radical scavengers mannitol and benzoate also inhibited the generation of phagocyte-generated SCEs supports this conclusion. The incomplete inhibition of oxidant-mediated SCE formation observed with these compounds is likely due to the design of the test system in which stimulated phagocytes are in close apposition to the $\mathrm{CHO}$ cells, preventing effective inactivation of the toxic products

Table V. Glutathione Levels in Hamster Ovary Cells Exposed to Sodium Selenite and Hypoxanthine Plus Xanthine Oxidase

\begin{tabular}{|c|c|c|c|}
\hline Additions to cell cultures & Glutathione/mg protein & Glutathione level & SCES \pm SEM \\
\hline & nmol & \% control & \\
\hline 1 Control & $39.3 \pm 2.9 \ddagger$ & 100 & $9.13 \pm 0.50$ \\
\hline $\begin{array}{l}2 \text { Hypoxanthine + xanthine oxidase } \\
\text { Hypoxanthine + xanthine oxidase }\end{array}$ & $39.6 \pm 3.6$ & 100 & $20.24 \pm 1.18 \S$ \\
\hline $3+$ sodium selenite $\left(10^{-4} \mathrm{M}\right)$ & $31.7 \pm 2.5$ & 80 & $28.04 \pm 2.38^{\prime \prime}$ \\
\hline $4+$ sodium selenite $\left(10^{-3} \mathrm{M}\right)$ & $28.6 \pm 3.9$ & 73 & Cytotoxicity \\
\hline
\end{tabular}

* Control consisted of $\mathrm{CHO}$ cells alone. $¥$ Mean \pm range from two experiments. $\S P<0.0005$ vs. 1 . " $P<0.0005$ vs. 2 . I Cytotoxicity is defined as no visible $\mathrm{CHO}$ cells at the time of harvest. 
before they contacted targets on the cell. Also, superoxide dismutase, catalase, and mannitol do not readily penetrate the cell and thus might only remove extracellular reactants. Finally, some of the oxygen products may react with components of the cell resulting in the formation of toxic intermediate compounds not degraded by the antioxidants studied.

Despite the evidence for the hydroxyl radical as an intermediary leading to SCEs, it is unlikely that the hydroxyl radical produced by phagocytes in the extracellular medium causes SCEs directly. The hydroxyl radical is so unstable in aqueous media that it reacts essentially when initially formed and has very little target specificity (22). The damage leading to SCE formation must ultimately influence the cell nucleus. Although hydrogen peroxide and superoxide anion not degraded by cytoplasmic scavenging systems could theoretically react in the nucleus to produce hydroxyl radicals, mannitol, which does not permeate cells, would not be expected to inhibit this process.

Hydroxyl radicals can react with membrane lipids to yield a variety of secondary radicals $(23,24)$. These products are longer-lived than hydroxyl radicals and could eventually influence events in the nucleus. The effects of vitamin $E$ and $\beta$-carotene are consistent with this idea. Vitamin $\mathrm{E}$ has been shown to inhibit carcinogenesis in animals and reduce mutations in some bacterial testing systems $(25,26)$. Vitamin $E$ is a hydrophobic antioxidant, and it is believed that its principal function is to protect the lipid material of an organism from uncontrolled, spontaneous autoxidation $(27,28)$. When target $\mathrm{CHO}$ cells were cultivated with vitamin $\mathrm{E}$ and then exposed to a cell-free oxidizing system, little chromosomal damage occurred. Although membrane concentrations of vitamin $\mathrm{E}$ were not measured directly, it is likely that vitamin $E$ is membrane associated in this system to provide protection, because free vitamin $\mathrm{E}$ was washed out of the medium prior to the oxidant stress. Because vitamin $\mathrm{E}$ protects against membrane fatty acid oxidation, it is possible that a membranederived, fatty acid oxidation product acts as an intermediate for the genetic damage we observed.

Vitamin E was protective against SCE formation induced when the vitamin present in the medium during exposure of target cells to phagocytes, but not to hypoxanthine and xanthine oxidase (even though the quantity of superoxide anion produced in each system was comparable-unpublished data). These data suggest, but do not prove, that vitamin E may be affecting the phagocyte directly, because it would have protected the target cells exposed to a cell-free oxidizing system had it been acting merely as an antioxidant. Vitamin E supplementation of the human diet results in neutrophils which undergo a normal respiratory burst, but release far less than the normal amount of hydrogen peroxide (29).

$\beta$-Carotene reduced the number of oxidant-induced SCEs in both the cellular and cell-free oxidant-generating systems studied. $\beta$-Carotene is a quencher of singlet oxygen but also can function as an effective radical-trapping antioxidant $(30$, 31). $\beta$-Carotene does not have the structural features commonly associated with chain-breaking antioxidants and presumably does not have to be membrane-bound to be effective as an antioxidant (32). $\beta$-Carotene does partition in biologic membranes, however, and it is not surprising that cells preincubated with $\beta$-carotene were protected from oxygen radical-induced chromosomal damage as well.
Glutathione plays a central role in the antioxidant defenses of cells (33). It is a cofactor of the enzyme glutathione peroxidase, which can detoxify both hydrogen peroxide and lipid hydroperoxides (34). Therefore, by depleting hydrogen peroxide, glutathione is expected to be important for preventing hydroxyl radical formation from superoxide anion and hydrogen peroxide and also for degrading lipid peroxides formed from the reaction of membranes with hydroxyl radicals. In cells treated with hypoxanthine and xanthine oxidase alone, glutathione levels were equal to those in controls, reflecting the activity of glutathione reducing and generating systems in the cell, yet a large number of SCEs were induced. Therefore, normal glutathione levels are insufficient to protect the cell from large oxidant fluxes, and it is not surprising that a modest fall in total glutathione levels would be associated with a very significant rise in genetic toxicity.

To determine whether a reduction in total glutathione levels would render the cell more susceptible to oxidantinduced chromosomal damage, glutathione production was blocked in BSO-treated cells $(35,36)$. SCEs were increased in cells treated with BSO alone and this effect was greatly magnified when an oxidant stress was added. In addition, there was a marked delay in DNA replication in these same cells which, in addition to SCEs, is a marker of toxicity (20). Conversely, the reduction in phagocyte-generated SCEs by $\mathrm{N}$-acetylcysteine could be explained in part by its effect as a glutathione-like agent on oxidants directly (37).

Selenium is a prosthetic group essential for the catalytic activity of glutathione peroxidase (38). Sodium selenite has been shown to be anticarcinogenic, antimutagenic, and anticlastogenic (39-42), and it has been suggested that adequate dietary selenium has a protective effect against the development of cancer in man (43). However, sodium selenite can also induce SCEs, unscheduled DNA synthesis, and chromosomal aberrations under certain conditions (44-46). SCE induction by sodium selenite occurs only if erythrocytes are added to the incubation medium, whereas for unscheduled DNA synthesis, glutathione must be present, indicating that a metabolite of sodium selenite is responsible for the damage $(44,46)$. The first two intermediates of sodium selenite metabolism are selenodiglutathione and glutathione selenopersulfide, whose formation requires reduced glutathione and glutathione reductase, respectively. Glutathione selenopersulfide is then converted to elemental selenium or hydrogen selenide (47).

In this study, erythrocytes were not present in the incubation medium, and no increase in SCEs with selenite alone was observed. In the presence of an oxidant stress, however, an augmentation in SCEs was seen at high concentrations of sodium selenite, whereas low concentrations resulted in a diminution of SCEs compared to controls. The latter effect may have been due to an induction or stabilization of glutathione peroxidase, resulting in a higher level of protection from oxygen radical-induced damage (48).

The detrimental effects of high concentrations of sodium selenite may be related to its interaction with glutathione. Because sodium selenite can convert glutathione to the disulfide, selenodiglutathione, it was predicted that total glutathione levels would fall in cells exposed to high concentrations of selenium. Total glutathione levels fell significantly in cells incubated with $10^{-3}$ and $10^{-4} \mathrm{M}$ sodium selenite and then exposed to an oxidant stress. This decrease in oxidant defense 
correlated with an increase in chromosomal and somatic toxicity.

\section{Acknowledgments}

This work was supported by grants CA-07147-02 and CA-09321 from the National Institutes of Health, by grant CD-190 to Dr. Weitzman from the American Cancer Society, by Edwin W. Hiam, The Council for Tobacco Research (1404), and by the Edwin S. Webster Foundation.

\section{References}

1. Klebanoff, S. J. 1980. Oxygen metabolites and the toxic properties of phagocytes. Ann. Intern. Med. 93:480-489.

2. Babior, B. M. 1978. Oxygen-dependent microbial killing by phagocytes. N. Engl. J. Med. 298:659-721.

3. Rinehart, J. J., P. Lange, B. J. Gorman, and M. E. Kaplan. 1978. Human monocyte-induced tumor cell cytotoxicity. Blood. 52: 211-220.

4. Weitzman, S. A., and T. P. Stossel. 1981. Mutation caused by human phagocytes. Science (Wash. DC). 212:546-547.

5. Weitberg, A. B., S. A. Weitzman, M. Destrempes, S. A. Latt, and T. P. Stossel. 1983. Stimulated human phagocytes produce cytogenetic changes in cultured mammalian cells. $N$. Engl. J. Med. 308: 26-29.

6. Quie, P. G., J. G. White, B. Holmes, and R. A. Good. 1967. In vitro bactericidal capacity of human polymorphonuclear leukocytes: diminished activity in chronic granulomatous disease in childhood. $J$. Clin. Invest. 46:668-679.

7. Holmes, B., A. R. Page, and R. A. Good. 1967. Studies of the metabolic activity of leukocytes from patients with a genetic abnormality of phagocytic function. J. Clin. Invest. 46:1422-1432.

8. Weitzman, S. A., A. B. Weitberg, E. P. Clark, and T. P. Stossel. 1985. Phagocytes as carcinogens: malignant transformation produced by human neutrophils. Science (Wash. DC). 227:1231-1233.

9. Zimmerman, R., and P. Cerutti. 1984. Active oxygen acts as a promoter of transformation in mouse embryo $\mathrm{C} 3 \mathrm{H} / 10 \mathrm{~T} 1 / 2 / \mathrm{C} 18$ fibroblasts. Proc. Natl. Acad. Sci. USA. 81:2085-2087.

10. Klock, J. C., and T. P. Stossel. 1977. Detection, pathogenesis, and prevention of damage to human granulocytes caused by interaction with nylon wool fiber: implications for filtration leukapheresis. J. Clin. Invest. 60:1183-1190.

11. McCullough, J., B. J. Weiblen, A. R. Deinard, J. Boen, I. E. Fortuny, and P. G. Quie. 1976. In vitro function and post-transfusion survival of granulocytes collected by continuous-flow centrifugation and by filtration leukapheresis. Blood. 48:315-326.

12. Babior, B. M., R. S. Kipnes, and J. T. Curnutte. 1973. Biological defense mechanism: the production by leukocytes of superoxide, a potential bactericidal agent. J. Clin. Invest. 52:741-744.

13. Goldstein, B. D., G. Witz, M. Amoruso, D. S. Stone, and W. Troll. 1981. Stimulation of human polymorphonuclear leukocytes superoxide anion radical production by tumor promoters. Cancer Lett. 11:257-262.

14. McCord, J. M., and I. Fridovich. 1969. Superoxide dismutase: An enzymic function for erythrocuprein (hemocuprein). J. Biol. Chem. 244:6049-6055.

15. Latt, S. A. 1974. Sister chromatid exchanges, indices of human chromosome damage and repair. detection by fluorescence and induction by mitomycin C. Proc. Natl. Acad. Sci. USA. 71:3162-3166.

16. Perry, P., and S. Wolff. 1974. New Giemsa method for the differential staining of sister chromatids. Nature (Lond.). 251:156-158.

17. Mitchell, J. B., A. Russo, T. J. Kinsella, and E. Glatstein. 1983. Glutathione elevation during thermotolerance induction and thermosensitization by glutathione depletion. Cancer Res. 43:987-991.

18. Clark, E. P., E. R. Epp, J. E. Biaglow, M. Morse-Gaudio, and E. Zachgo. 1984. Glutathione depletion, radiosensitization, and mison- idazole potentiation in hypoxic chinese hamster ovary cells by buthionine sulfoximine. Radiat. Res. 98:370-380.

19. Tietze, F. 1969. Enzymatic method for quantitative determination of nanogram amounts of total and oxidized glutathione. Anal. Biochem. 27:502-522.

20. Tice, R., E. L. Schneider, and J. M. Rary. 1976. The utilization of bromodeoxyuridine incorporation into DNA for the analysis of cellular kinetics. J. Clin. Invest. 102:232-236.

21. Weinstein, J., and B. H. J. Bielski. 1979. Kinetics of the interaction of $\mathrm{HO}_{2}$ and $\mathrm{O}_{2}$ radicals with hydrogen peroxide: the HaberWeiss reaction. J. Am. Chem. Soc. 101:58-62.

22. Beauchamp, C., and I. Fridovich. 1970. A mechanism for the production of ethylene from methanol: generation of the hydroxyl radical by xanthine oxidase. J. Biol. Chem. 245:4641-4646.

23. Fridovich, S. E., and N. A. Porter. 1981. Oxidation of arachidonic acid in micelles by superoxide and hydrogen peroxide. J. Biol. Chem. 256:260-265.

24. Pietronigro, D. D., W. B. G. Jones, K. Kalty, and H. B. Demopoulos. 1977. Interaction of DNA and liposomes as a model for membrane-mediated DNA damage. Nature (Lond.). 267:78-79.

25. Shamberger, R. J., C. L. Corbett, K. D. Bearman, and B. L. Kasten. 1979. Antioxidants reduce the mutagenic effect of malonaldehyde and beta-propriolactone. IX. Antioxidants and cancer. Mutat. Res. 66:349-355.

26. Weitzman, S. A., and T. P. Stossel. 1982. Effects of oxygen radical scavengers and antioxidants on phagocyte-induced mutagenesis. J. Immunol. 128:2770-2772.

27. Witting, L. A. 1980. Vitamin E and lipid antioxidants in freeradical-initiated reactions. In Free Radicals in Biology, Vol. IV. W. A Pryor, editor. Academic Press, Inc., New York. 295-319.

28. Bieri, J., L. Corash, and V. S. Hubbard. 1983. Medical uses of vitamin E. N. Engl. J. Med. 308:1063-1071.

29. Butterick, M. S., R. L. Baehner, L. A. Boxer, and R. A. Jersild, Jr. 1983. Vitamin E-a selective inhibitor of the NADPH oxidoreductase enzyme system in human granulocytes. Am. J. Pathol. 112:287-292.

30. Foote, C. S. 1976. Photosensitized oxidation and singlet oxygen: Consequences in biological systems. In Free Radicals in Biology, Vol. II. W. A. Pryor, editor. Academic Press, Inc., New York. 85-133.

31. Burton, G. W., and K. U. Ingold. 1984. Beta-carotene: an unusual type of lipid antioxidant. Science (Wash. DC). 224:569-573.

32. Packer, J. E., J. S. Mahood, V. O. Mora-Arleno, T. F. Slater, and B. S. Wolfenden. 1981. Reactions of the trichloromethylperoxy free radical $\left(\mathrm{Cl}_{3} \mathrm{COO}\right)$ with tryptophan, tryptopanyl-tyrosine and lysozyme. Int. J. Radiat. 39:135-141.

33. Meister, A. 1983. Selective modification of glutathione metabolism. Science (Wash. DC). 220:472-477.

34. Leopold, F. 1976. Glutathione peroxidase brought into focus In Free Radicals in Biology, Vol. V. W. A. Pryor, editor. Academic Press, Inc., New York. 223-254.

35. Arrick, B. A., C. F. Nathan, O. W. Griffith, and Z. A. Cohn 1982. Glutathione depletion sensitizes tumor cells to oxidative cytolysis. J. Biol. Chem. 257:1231-1237.

36. Griffith, O. W., and A. Meister. 1979. Potent and specific inhibition of glutathione synthesis by buthionine sulfoximine $(S-N-$ butyl homocysteine sulfoximine). J. Biol. Chem. 254:7558-7560.

37. Speit, G., and W. Vogel. 1982. The effect of sulfhydryl compounds on sister-chromatid exchanges. II. The question of cell specificity and the role of $\mathrm{H}_{2} \mathrm{O}_{2}$. Mutat. Res. 93:175-183.

38. Chow, C. K. 1979. Nutritional influence on cellular antioxidant defense systems. Am. J. Clin. Nutr. 32:1066-1081.

39. Shamberger, R. J. 1970. Relationship of selenium to cancer. I. Inhibitory effect of selenium on carcinogenesis. J. Natl. Cancer Inst. 44:931-936.

40. Ip, C. 1981. Prophylaxis of mammary neoplasia by selenium supplementation in the initiation and promotion phases of chemical carcinogenesis. Cancer Res. 41:4386-4390. 
41. Rosin, M. P., and H. F. Stitch. 1979. Assessment of the use of the Salmonella mutagenesis assay to determine the influence of antioxidants on carcinogen-induced mutagenesis. Int. J. Cancer. 23:722-727.

42. Shamberger, R. J., F. F. Baughman, S. L. Kalchert, C. E. Willis, and G. C. Hoffman. 1973. Carcinogen-induced chromosomal breakage decreased by antioxidants. Proc. Natl. Acad. Sci. USA. 70: $1462-1463$.

43. Shamberger, R. J., S. A. Tytko, and C. E. Willis. 1971. Antioxidants and cancer. IV. Selenium and age-adjusted human cancer mortality. Arch. Environ. Health. 31:231-235.

44. Ray, J. H., and L. C. Altenburg. 1978. Sister-chromatid exchange induction by sodium selenite: dependence on the presence of red blood cells or red blood cell lysate. Mutat. Res. 54:343-354.

45. Lo, L. W., J. Koropatnick, and H. F. Stitch. 1978. The mutagenicity and cytotoxicity of selenite, "activated selenite" and selenate for normal and DNA repair-deficient human fibroblasts. Mutat. Res. 49:305-312.

46. Whiting, R. F., L. Wei, and H. F. Stitch. 1980. Unscheduled DNA synthesis and chromosome aberrations induced by inorganic and organic selenium compounds in the presence of glutathione. Mutat. Res. 78:159-169.

47. Ray, J. H., and L. C. Altenburg. 1982. Sister-chromatid exchange induction by sodium selenite. Plasma protein-bound selenium is not the active SCE-inducing metabolite of $\mathrm{Na}_{2} \mathrm{SeO}_{3}$. Mutat. Res. 102:285-296.

48. Borek, C., L. Donahue, and J. E. Biaglow. 1985. Mechanism for selenium protection against radiation carcinogenesis. Radiat. Res. In press. 